\title{
Assessment of the durability of low-cost Al bipolar plates for High
} Temperature PEM Fuel Cells

\author{
Cinthia Alegre*, Laura Álvarez-Manuel, Radu Mustata, Luis Valiño, \\ Antonio Lozano, Félix Barreras \\ Laboratorio de Investigación en Fluidodinámica y Tecnologías de la Combustión \\ LIFTEC, CSIC-Univ. of Zaragoza, C/ María de Luna, 10. 50018, Zaragoza (Spain) \\ *Corresponding author: alegre@liftec.unizar-csic.es
}

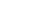

\section{Abstract}

The present research aims to assess the durability of a single cell formed by a commercial high-temperature membrane electrode assembly (MEA) and Al bipolar plates (Al-BPPs) coated with Ni-P. To this end, an accelerated degradation test based on voltage load cycles is carried out, and the effects of the degradation on the MEA and its impact on the Alcoated bipolar plates are analyzed. They are compared with the results obtained testing a similar cell formed by the same MEA with graphite plates. MEAs from both cells were analyzed by different characterization techniques before and after the degradation tests (XRD, SEM, TEM). The performance of the Al-based cell is initially better, but it suffers a faster deterioration mainly due to the degradation of the Ni-P surface coating. A green deposit is formed, probably due to the chemical reaction of the phosphoric acid leached from the MEA. These deposits cause an increase in the contact resistance of the plates, local channel blockages and, eventually, a larger degradation. This work proves that PBI membranes still need to be improved to ensure their long-term durability.

Keywords: High temperature PEM fuel cell; Aluminum bipolar plates; Ni-P coating; MEA degradation; stress test 


\section{Introduction}

Compared to low temperature proton exchange membrane fuel cells (LT-PEMFCs), hightemperature (HT-PEMFCs) ones offer several advantages like enhanced kinetics of the electrochemical reactions, simplified water and heat management, and better suitability to be integrated in combined heat and power (CHP) units [1-3]. These features make them promising candidates not only for the automotive sector but also for stationary applications, and have led to an increased research interest in the last years $[2,4]$.

HT-PEMFCs are usually based on a phosphoric acid doped polybenzimidazole (PBI) membrane, instead of the Nafion one commonly used in LT-PEMFCs [5-7]. This type of membrane allows working at higher temperatures $\left(120-200^{\circ} \mathrm{C}\right)$, without humidification and with fuels with a higher amount of impurities [1,2,8,9].

Although great advances have been made in PEM fuel cell technology along the years, there are several issues still limiting their widespread commercialization [10-12]. In the case of HT-PEMFCs, the main issues to deal with are: the cost (Pt-based catalysts with high Pt loadings are the most used), durability and performance degradation $[2,6,13]$. According to the DOE's requirements, PEMFCs should last for $5000 \mathrm{~h}$ for automotive applications and around $60,000 \mathrm{~h}$ for stationary ones [2,14-16]. It has been proven that under steady state operation conditions, HT-PEMFCs can reach up to $17,000 \mathrm{~h}$ of operation lifetime. However under variable load conditions, their lifetime still needs to be extended $[13,17]$. There is a great margin for improvement in the durability of these systems and so, understanding the mechanisms of fuel cell degradation is mandatory.

Performance decay of HT-PEMFCs operating with phosphoric acid doped-PBI membranes is due to two main factors: reduction of the catalyst active area (caused by both agglomeration of metallic nanoparticles and carbon corrosion) and phosphoric acid migration $[13,18-23]$. The loss of phosphoric acid causes a decrease of the membrane 
51 ionic conductivity and so a malfunction of the cell $[13,24]$. This malfunction can lead to

52 the degradation of other cell components, such as the bipolar plates (BPPs) [18]. BPPs are one of the most significant parts of a fuel cell stack, accounting for more than half of its cost and weight [25-27]. The BPP properties that mainly affect the performance of fuel cells are both the corrosion and the contact resistance [28].

BPPs have been thoroughly investigated for many years. They can be manufactured in different materials: mainly, carbon based compounds (graphite, carbon composites, etc.) and metallic alloys (stainless steel, aluminum or titanium, among others). When using metallic plates, it is necessary to protect them with different coatings, in order to increase their resistance to corrosion [25,28-30].

Conventionally, substrates made of graphite have been mostly used as bipolar plates in PEMFCs, due to their good resistance to corrosion. However, metallic BPPs have also been considered, particularly for LT-PEMFCs, due to their lower cost, lower weight and volume (especially when thin films are used), and an easier manufacture than graphitebased ones $[31,32]$. For HT-PEMFCs, the use of metallic BPPs has only been recently considered [18,33-38]. HT-PEMFCs present a more corrosive environment in comparison to LT-PEMFCs, due to the higher temperature of operation, that enhances corrosion processes in acidic environments. Requirements for BPPs in HT-PEMFCs are thus more demanding. It has been proved that graphite plates in HT-PEMFC become porous, up-taking higher amounts of electrolyte (phosphoric acid) and causing a faster degradation of the membrane electrode assembly (MEA), due to the redistribution of the acid $[18,29]$.

Metallic BPPs are considered a promising alternative for HT-PEMFCs, in order to minimize the effects of phosphoric acid up-take, as well as to reduce the total weight and cost of the stack [34,38]. Some authors have studied stainless steel BPPs, coated with 
different materials to increase their resistance to corrosion like $\mathrm{Au}, \mathrm{Ni}$, etc $[30,34,35]$.

Aluminum is another light and cheap metal than has been widely used as BPP substrate in LT-PEMFCs [28,31,39-42]. However, the use of Al-based BPPs for HT-PEMFCs has been very limited $[33,36,38]$. Several coatings have been studied to increase the resistance to corrosion of Al-based BPPs (Ni, Ni-P, NiCo, etc) in LT-PEMFCs. Among them Ni-P and Ni-Mo have shown the best results in terms of corrosion resistance $[25,40]$.

The present research aims to investigate the durability of a single cell formed with a commercial MEA and cost-effective Al plates coated with Ni-P. To this end, accelerated degradation tests were carried out to induce the MEA degradation, and to analyze its effect on the bipolar plates. A comparison with a cell made of graphite plates was also performed. Since life-time tests are impractical due to the their long duration $[3,43,44]$, a new accelerated stress test based on voltage load cycles was designed for this study. The aim was to subject the cells to a high stress, analyzing the effects of the degradation on both the MEAs and the coated Al plates.

\section{Experimental}

\subsection{HT-PEMFC single cell}

The MEA used for the measurements is a Celtec $\AA-P 1100$ supplied by BASF Fuel Cells, with a standard rectangular active area of $81.28 \mathrm{~cm}^{2}$. Celtec-P high-temperature membrane consists in a polybenzimidazole (PBI) immobile gel phase doped with concentrated phosphoric acid (PA) that ensures an adequate proton conductivity and gas permeability [45-48]. The operating temperature was $120^{\circ} \mathrm{C}$ (no humidification for the reactant gases needed). The cathode contains a Vulcan XC 72 supported Pt-alloy with $0.75 \mathrm{mg} \mathrm{Pt} \mathrm{cm}^{-2}$, whereas the anode contains a Vulcan XC 72 supported Pt catalyst with $1 \mathrm{mg} \mathrm{Pt} \mathrm{cm}^{-2}$. According to the manufacturer, membrane thickness in the MEA is 
approximately 50-75 $\mu \mathrm{m}$. The gas diffusion layer (GDL) is composed of woven carbon cloth [33].

For the present experiments, two single cells were manufactured using graphite and aluminum plates, respectively. A serpentine-parallel geometry formed by 3 blocks of 10 channels with a total length of $392.4 \mathrm{~mm}$ was selected to cover the whole flowfield area in both anode and cathode sides. The channels of the anode electrode have a rectangular cross section $1 \mathrm{~mm}$ wide and $0.5 \mathrm{~mm}$ deep, spaced by ribs $1 \mathrm{~mm}$ thick, while those of the cathode side have a squared cross section of $1 \times 1 \mathrm{~mm}^{2}$. For a current density of $0.45 \mathrm{~A} \mathrm{~cm}^{-2}$, and flow stoichiometry of 1.2 for hydrogen, and 2 for oxygen, the reactant gases flowrates are $0.34 \mathrm{Nl} \mathrm{min}{ }^{-1}$ and $0.31 \mathrm{Nl} \mathrm{min}^{-1}$, respectively. So, the design of the selected geometry flowfield ensures the homogeneous distribution of reactant gases over the catalyst layers reducing the total pressure drop [49-52]. A receded housing of $0.2 \mathrm{~mm}$ was manufactured for the area where the MEAs are positioned, ensuring a good electrical contact and simultaneously a maximum compression rate of $80 \%$, as recommended by the manufacturer. It is also important to note that, to protect the aluminum plates from the corrosion caused by the acid media, a $40 \mu \mathrm{m}$ thick Ni-P (10-12\% P) thin layer was deposited over the whole surface using electroless techniques [33].

\subsection{Physical-chemical characterization}

MEAs were analyzed by different characterization techniques before and after the stress tests, in order to investigate the effects of degradation on the physical-chemical features. X-ray diffraction (XRD), performed in a Bruker AXS D8 Advance diffractometer with a $\theta-\theta$ configuration and using $\mathrm{Cu}-\mathrm{K} \alpha$ radiation, was used to analyze the Pt crystallite size from both the cathode and the anode electrodes. Crystallite sizes were calculated from the Scherrer's equation on the (2 20$)$ peak. Particle size and morphology of Pt particles on 
both anode and cathode were investigated with transmission electron microscopy using a JEOL JEM-2000 FX II microscope. Morphological features of both fresh and used MEAs were observed by analyzing a cross-section with scanning electron microscopy (SEM, Hitachi S-3400 N). X-ray fluorescence spectroscopy (XRF) was performed in an ADVANT'XP Thermo Electron, ARL series spectrometer with a Rh X-ray tube, using UNIQUANT software for the semi-quantitative analysis of the bipolar plates after the degradation studies.

\subsection{Single-cell characterization}

All the tests were performed in the dual test bench available at LIFTEC research facilities. After flowing dry $\mathrm{N}_{2}$ to verify that there were no leaks of reactant gases, the following conditioning procedure was followed. In short, the cells were heated up to $120^{\circ} \mathrm{C}$ using a commercially available pyrolysis furnace from Fagor, model FAR FC $801 \mathrm{X}$, which incorporates a forced air fan to have a precise control of the heating temperature. After that, small flows of $\mathrm{H}_{2}$ and $\mathrm{O}_{2}$ were supplied to anode and cathode sides in order to remove the remaining $\mathrm{N}_{2}$, and to fill the channels of the flowfield geometry with reactant gases. Once the device was ready, a high voltage was fixed in the electronic load $(0.8 \mathrm{~V})$, which was maintained until the current generated by the device reached the steady state. After that, the electronic load working mode was changed to demand a constant current, which was slowly increased from $0.01 \mathrm{~A}$ to $16.3 \mathrm{~A}\left(0.2 \mathrm{~A} \mathrm{~cm}^{-2}\right)$, increasing also the pressure of the reactant gases up to 0.3 bar. For every value, both hydrogen and oxygen flows were automatically adjusted considering stoichiometry of 1.45 and 9 , respectively, as recommended by the MEA manufacturer. When the current produced remained constant at 16.3 A, the cells were kept in this working point for 8-10 hours, verifying that the electrical performance was stationary. 

degradation test. The cells were placed inside the commercial oven, and when the temperature reached $120^{\circ} \mathrm{C}$ (recommended by the MEA manufacturer), a constant voltage

$152(0.8 \mathrm{~V})$ was demanded by the electronic load until the generated current was stabilized.

153 A constant pressure of 0.3 bar was set for both hydrogen and oxygen, and the flowrates were fixed to $0.15 \mathrm{Nl} \mathrm{min}{ }^{-1}$ and $0.13 \mathrm{Nl} \mathrm{min}{ }^{-1}$, respectively (stoichiometry of 1.2 and 2). Then, charge cycles began every 15 minutes, changing the demanded voltage between $0.97 \mathrm{~V}$ and $0.1 \mathrm{~V}$, and verifying the corresponding value of the generated current. It should be noted that working with such low voltage is neither typical in practical applications nor in other accelerated stress test protocols. However, using this strategy it is possible to both reduce the testing time and to induce an intense test malfunctioning, being able to study the performance of the MEA under extreme conditions. The test was stopped after 5000 minutes ( 83 hours), or when the value of the current was around $20 \%$ of the initial one.

\section{Results and discussion}

\subsection{Physical-chemical characterization of the fresh MEA}

Figure 1 shows SEM images at low (Fig. 1a) and high (Fig. 1b) magnification of the fresh MEA. Several images were taken and the thickness of the MEA was measured in several points in order to obtain a distribution, shown in Fig. 1c. The mean thickness of the BASF Fuel Cell Membrane is around $57 \mu \mathrm{m}$, as also confirmed by other studies in the literature $[34,53]$. In the figure, the cathode is in the upper part of the picture and the anode in the bottom one. From the image at high magnification, it is clear that the anode has a higher concentration of metal (higher brightness level), also confirming the different 
173 loading for both electrodes [34,53]. The composition for the different components of the

174 MEA (cathode, anode and membrane) was determined by Scanning Electron Microscopy

175 coupled with Energy Dispersive X-ray spectroscopy (SEM-EDX). The membrane is

176 composed of $\mathrm{C}, \mathrm{O}$ and $\mathrm{P}$, as expected. On the other hand, anode and cathode electrodes,

177 show the presence of $\mathrm{P}$ due to phosphoric acid leached from the membrane when it is

178 exposed to room air. Both anode and cathode present also $\mathrm{F}$, that most probably comes

179 from the Teflon (PTFE), usually employed as binder in the preparation of the electrodes.
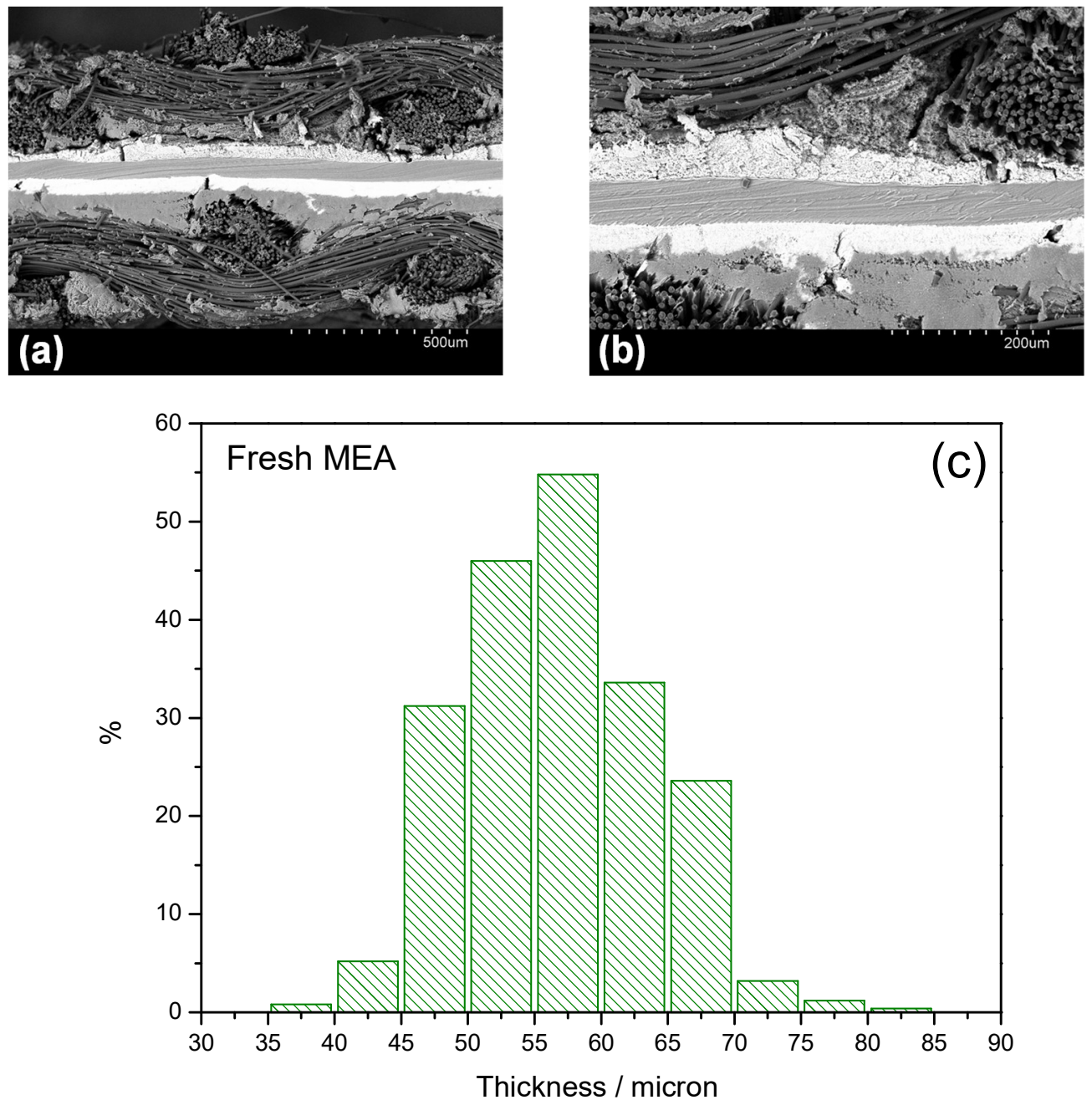

Figure 1. SEM images of fresh MEAs at lower (a) and higher (b) magnification. (c) histogram representing the thickness distribution. 
183 obtained from the fresh MEA. Catalysts were scratched from the MEA to obtain the 184 powder. Given the low amount of powder obtained, the resolution of the X-ray pattern is 185 not optimal, but it is good enough to determine the species present in both electrodes and 186 to estimate the Pt crystallite size. In both electrodes, the presence of Pt (green lines), C 187 (black line) and PTFE (blue lines, probably employed as binder in the preparation of the 188 ink for the electrode, as previously discussed) were detected. Crystallite sizes calculated by the Schrerrer's law were around $3.7 \mathrm{~nm}$ for the anode and $4.6 \mathrm{~nm}$ for the cathode.

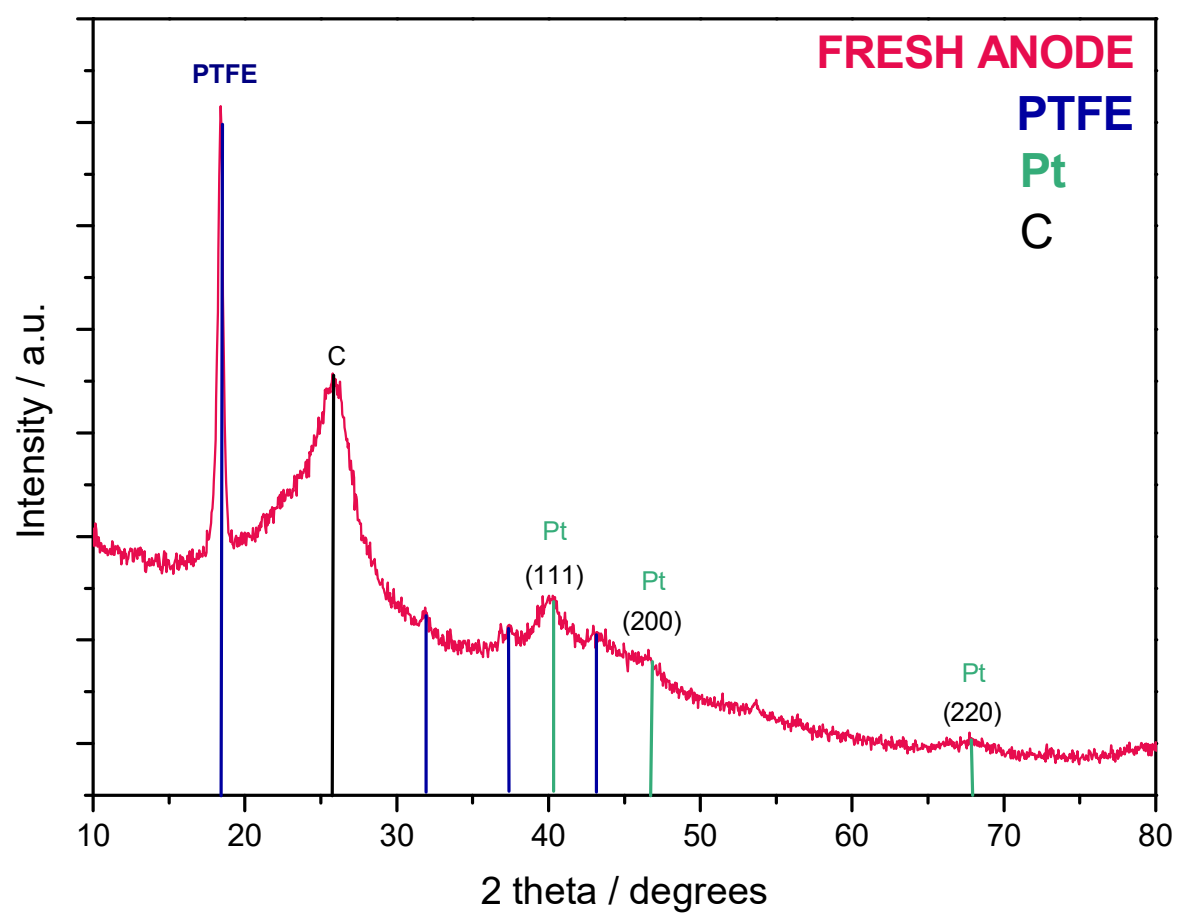




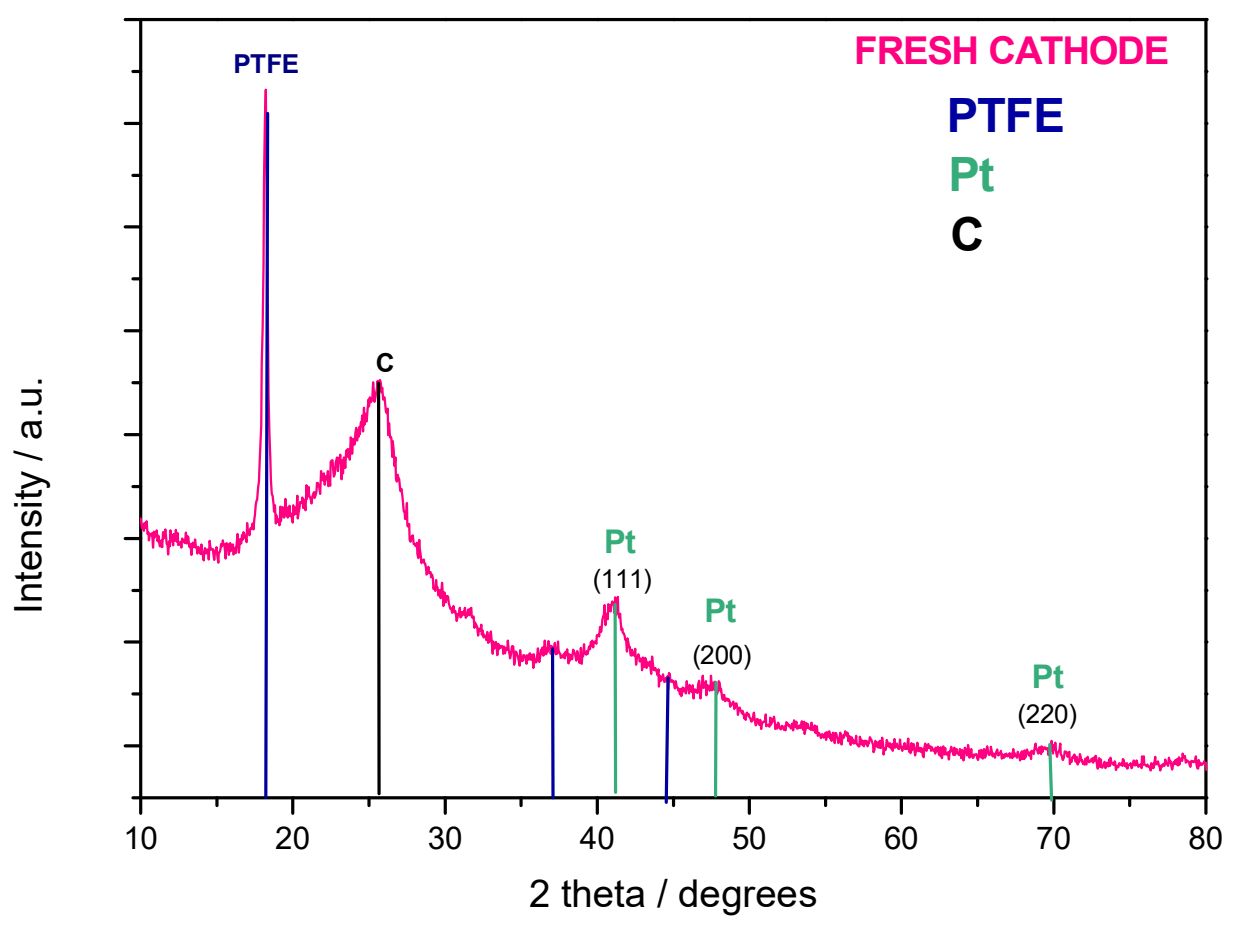

Figure 2. XRD diffraction patterns for both anode and cathode obtained from the fresh MEA (prior to use).

Figures 3a and $\mathbf{3 b}$ show TEM images obtained from the powders scratched from

192 the MEA. The cathode (Fig. 3a) presents a particle size distribution around $4.5 \mathrm{~nm}$, with

$193 \mathrm{Pt}, \mathrm{P}, \mathrm{C}$ and $\mathrm{O}$ as the main elements, determined by EDX, as also corroborated by SEM.

194 The anode (Fig. 3b) shows a smaller particle size distribution, around $3.5 \mathrm{~nm}$, and the

195 carbon surface appears less uniformly covered than in the case of the cathode. In this case,

196 it was more difficult to obtain a good image, due to the difficulties encountered scratching

197 the anode powder from the MEA. The composition is similar to the one obtained for the cathode. 

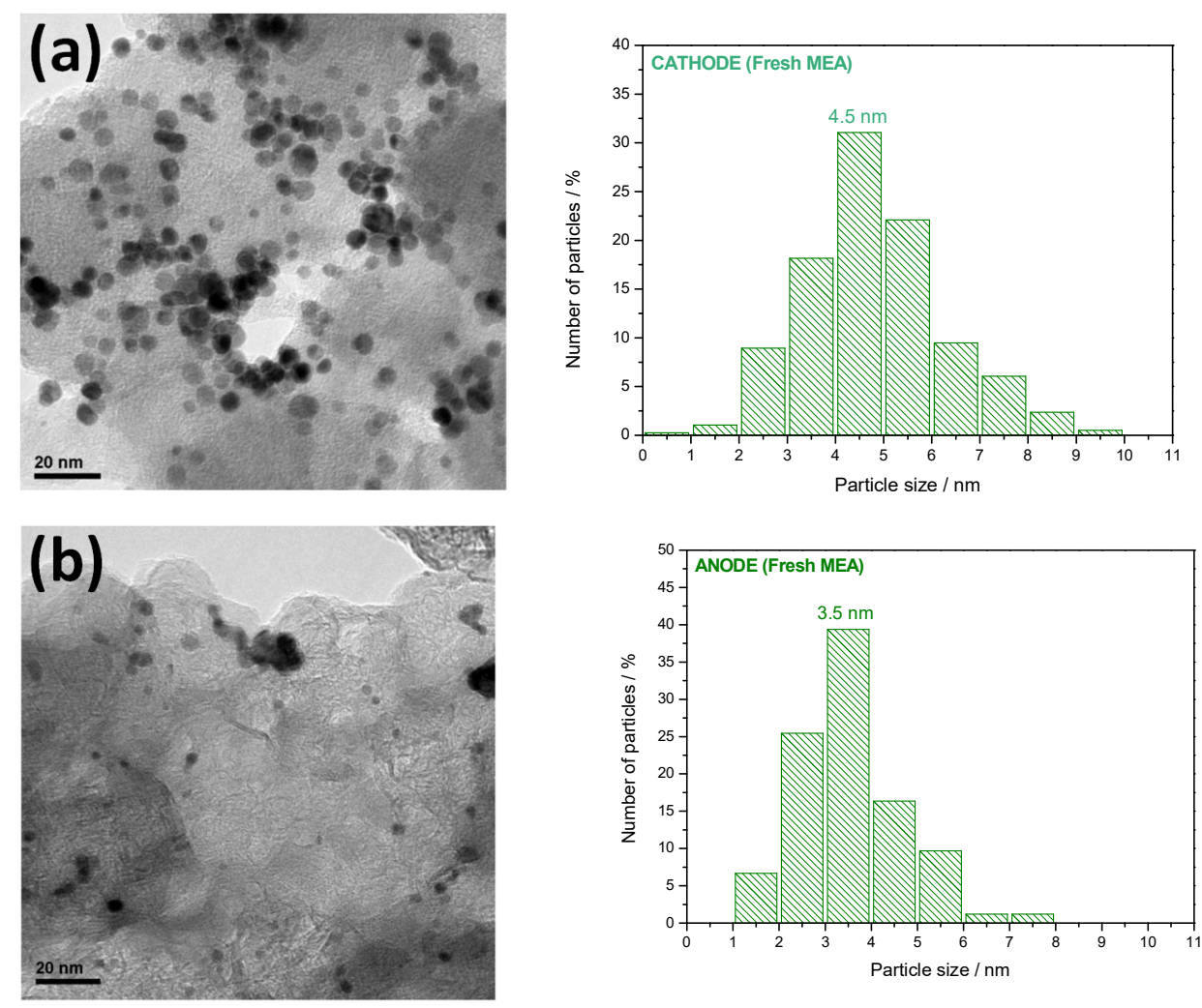

Figure 3. TEM images and particle size distribution for (a) fresh cathode and (b) fresh anode.

\subsection{Accelerated stress tests}

202

Figure 4 shows the current vs. time curves for both cells tested: (a) the one with Al-Ni-P plates and (b) the one made of graphite. The inset shows a zoom of the graph until the first 300 minutes. The variation of voltage (right axis) with current (left axis) is also plotted. As ascertained from the graphs, the single cell with Al-coated plates (Fig. 4a) shows a better initial current, $150 \mathrm{~mA} \mathrm{~cm}{ }^{-2}$ (around $12 \mathrm{~A}$ ) in comparison to the graphite-based single cell (Fig. 4b), for which the initial current was $85 \mathrm{~mA} \mathrm{~cm}^{-2}$ (around 7 A). This lower performance could be due to the porosity of the graphite, that could cause a larger initial ohmic resistance (higher contact resistance) as well as a higher intake of PA [18]. However, the graphite-based cell shows a slight improvement after the first 500 minutes of operation, reaching a current value around $100 \mathrm{~mA} \mathrm{~cm}{ }^{-2}$ at 1000 
212 minutes of test. The Al-Ni-P-based single cell however, shows a performance decay after

213 the first 500 minutes of operation and the current decreases to one half of the initial value.

214 The performance of both cells strongly decreases after 3000 minutes of experiment,

215 falling to currents of $30 \mathrm{~mA} \mathrm{~cm}^{-2}$. For the Al-coated cell it represents a current loss of

$21678.3 \%$ of its initial value, while for the graphite one the reduction is only of $54.2 \%$, but

217 working for more than 80 hours.

218 
(a) Al-Ni-P based single cell

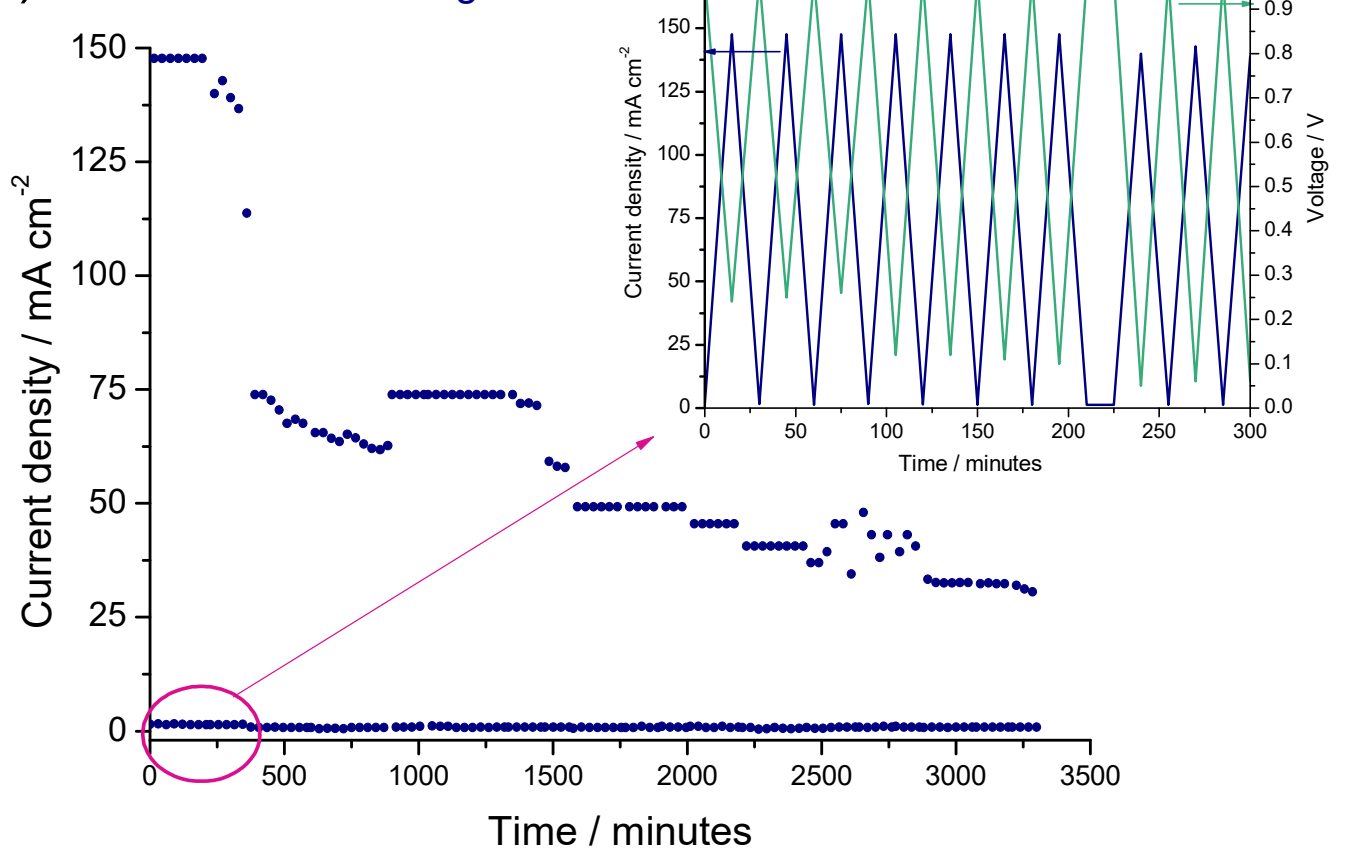

(b) Graphite based single cell

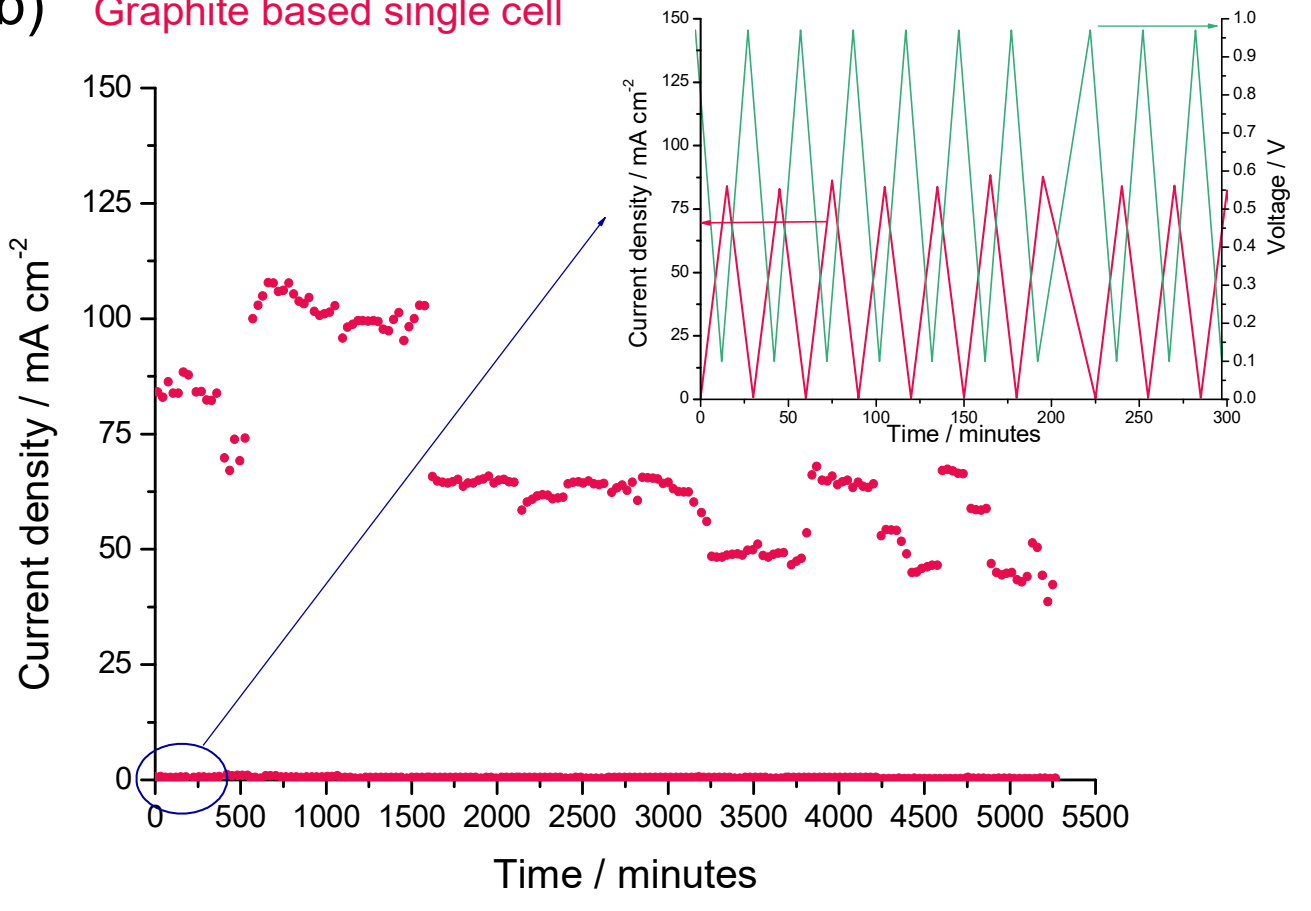

Figure 4. Current vs. time curve for (a) the Al-Ni-P-based single cell and (b) the graphite-based single cell. The inset shows a zoom of the variation of current with time for the first 500 minutes. 
A green deposit was found over the plate of both cathode and, especially, anode

222

223

224

225

226

227

228

229

230 graphite-based cell.
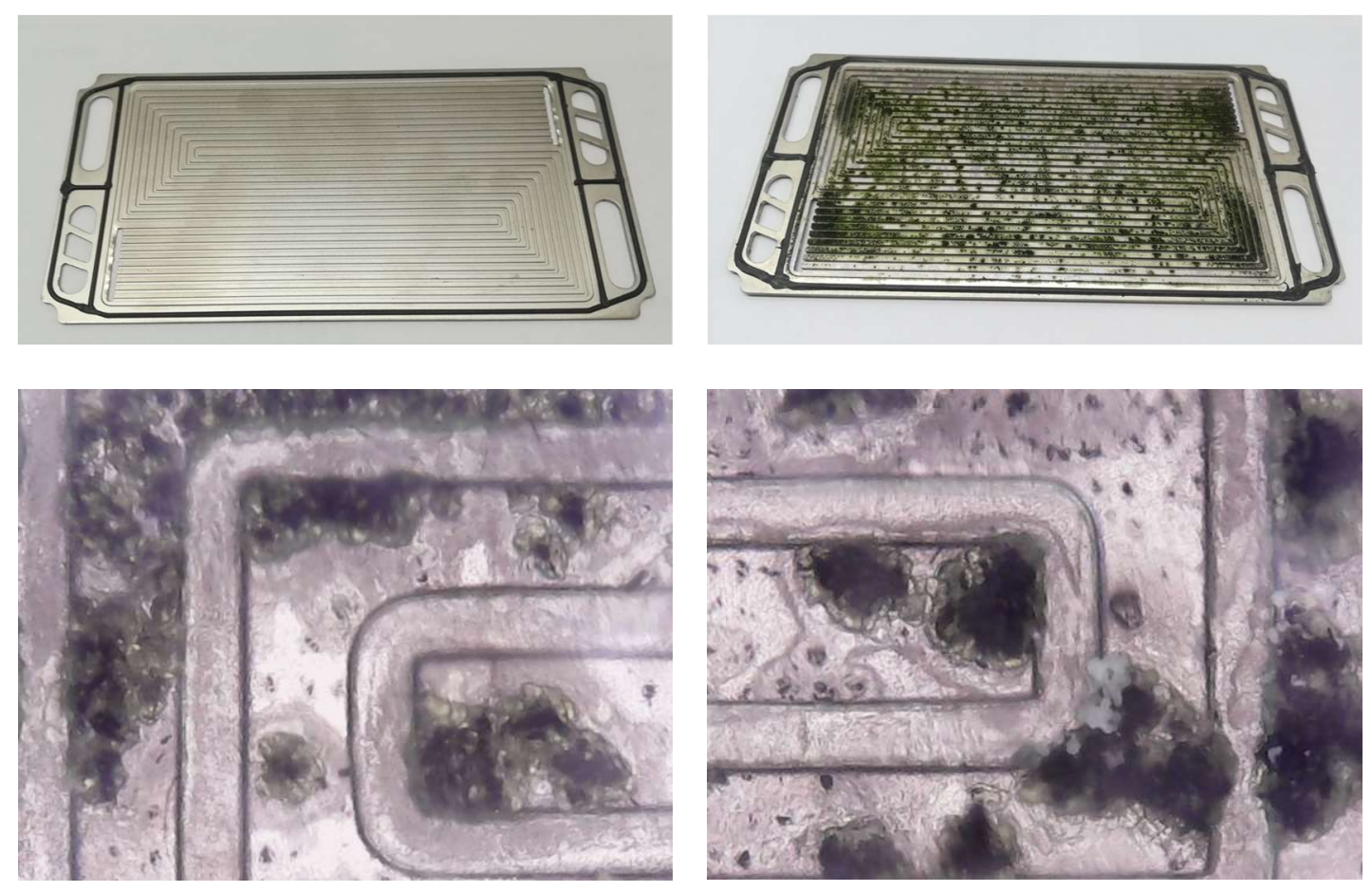

Figure 5. Images of the Al-Ni-P bipolar plates before (top left) and after (top right) the degradation studies and zoom (bottom) of the corroded plate obtained with a magnifying glass. 
A similar result was obtained by Alnegren et al. [28] who studied the degradation of stainless steel bipolar plates in a HT-PEMFC. They detected the formation of a green deposit mainly composed of phosphates on the anode side of the bipolar plates. Their cell was operated at $160^{\circ} \mathrm{C}$ and constant load of $200 \mathrm{~mA} \mathrm{~cm}^{-2}$ for $900 \mathrm{~h}$. Although tests are different (constant current load at $160^{\circ} \mathrm{C}$ versus dynamic voltage load at $120^{\circ} \mathrm{C}$ ), it is clear that both of them favor the leaching of the phosphoric acid (PA) towards the anode side. Reimer et al. determined the main driving force of water distribution when PA is used as an electrolyte [54]. They concluded that in HT-PEMFC operated with dry gases (as in our experiments), the PA in the anode electrode layer is highly concentrated and water concentration is very low. This result could explain the higher corrosion suffered from the anodic plate in our study as well as in the one by Alnegren. This fact was also corroborated by Eberhardt et al. that determined that PBI-based systems exhibit an extensive PA migration from cathode to anode, particularly under high current density operation [55] due to the charge balance. Hydrogen phosphate anions, negatively charged, carry on part of the ionic current, so a net movement of hydrogen phosphate from cathode performance decay of HT-PEMFCs.

The presence of the deposit on the Al-coated cell clearly causes a major degradation of its components, justifying its higher performance decay. It must be pointed out that the type of stress test performed is really aggressive, in order to study the behavior of these plates under extreme conditions in a short time. As previously explained, Al- 
257 due to degradation. Operation of this cell in a more conservative way should enlarge the 258 lifetime of the Al-Ni-P BPPs.

259

260

\subsection{Physical-chemical characterization of the used MEAs}

261

A cross-section of the used MEAs was analyzed after the stress tests by means of

262 SEM. Images obtained for the three studied MEAs, fresh and used from both Al-coated

263 and graphite-based cells are shown in Figure 6, along with the fitting of the thickness

264 histograms to a Gauss type curve (Fig. 6d). Yellow arrows indicate some of the points

265 where thickness measurements were taken. The thickness of the fresh MEA (Fig. 6a),

266 around $57 \mu \mathrm{m}$, is significantly reduced after the accelerated stress tests, when Al-Ni-P

267 BPPs were used (52 $\mu \mathrm{m}$, Fig. 6b). The thickness of the MEA from the graphite-based cell

268 (56 um) however, barely becomes affected by the degradation processes (Fig. 6c).

269 

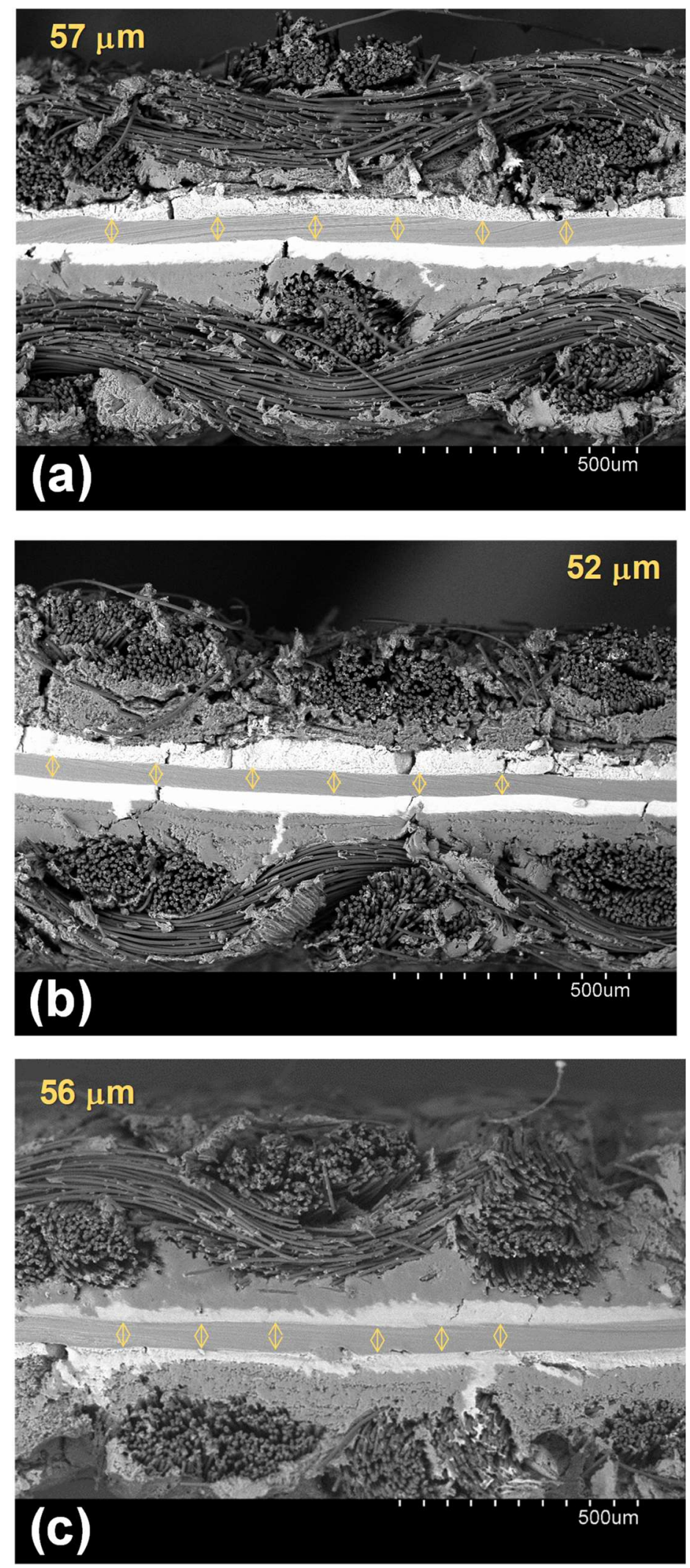


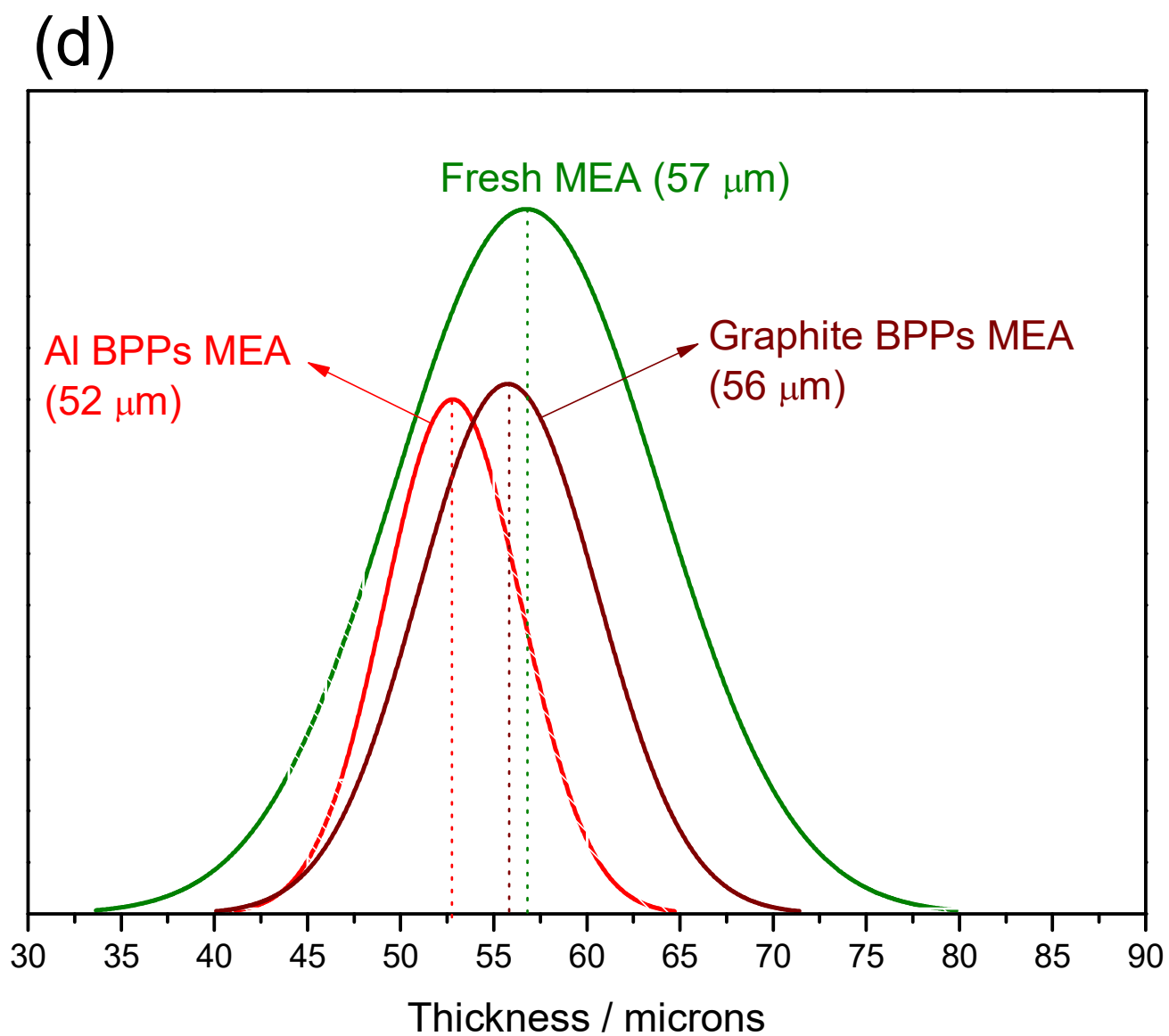

Figure 6. SEM images of (a) fresh MEA, (b) used MEA from the Al-Ni-P single cell and (c) used MEA from the graphite-based single cell. Arrows are placed to indicate example points in which thickness was measured. (d) Gauss fitting obtained from the thickness histograms of the different MEAs analyzed.

The composition of the MEA obtained from SEM-EDX analyses showed the presence of a small amount of $\mathrm{Ni}$ (around a $1.5 \mathrm{wt}$. \%) both in the cathode and the anode sides in the Al-Ni-P used MEA, evidencing the corrosion suffered by the plates. The Ni traces detected indicate that some PA leaching also occurred on this side, causing the degradation of the coating of the Al-plates due to chemical reaction. XRD patterns for the used MEAs, extracted from both cells, are shown in Fig. 7. The Al-Ni-P-based single cell (Fig. 7a and 7b), evidenced the increase of the crystallite size of $\mathrm{Pt}$, particularly in the cathode side, after the degradation tests. 
(a)

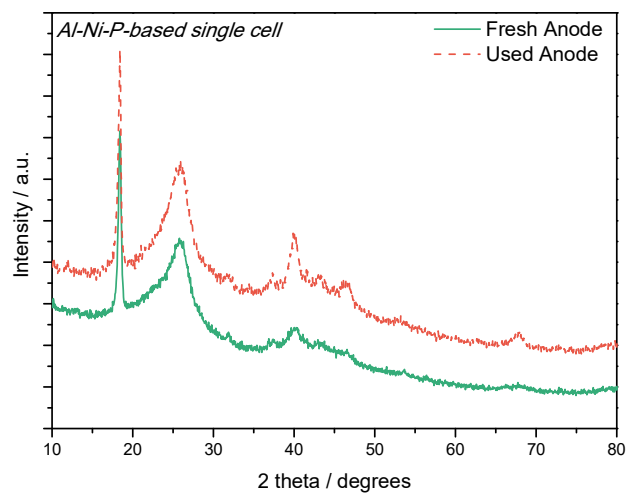

(c)

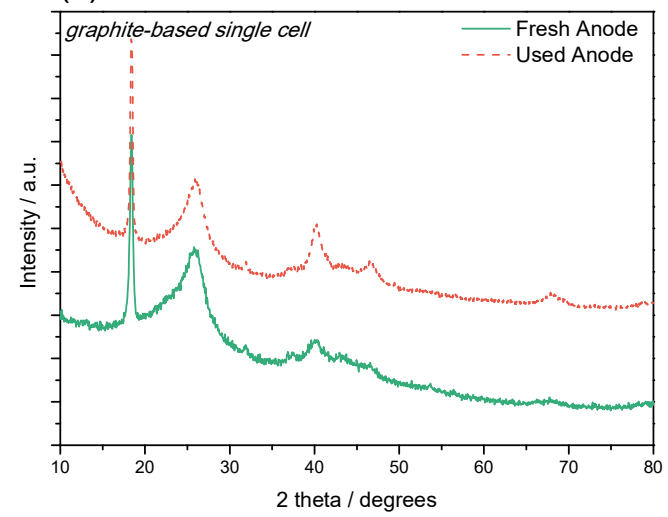

(b)

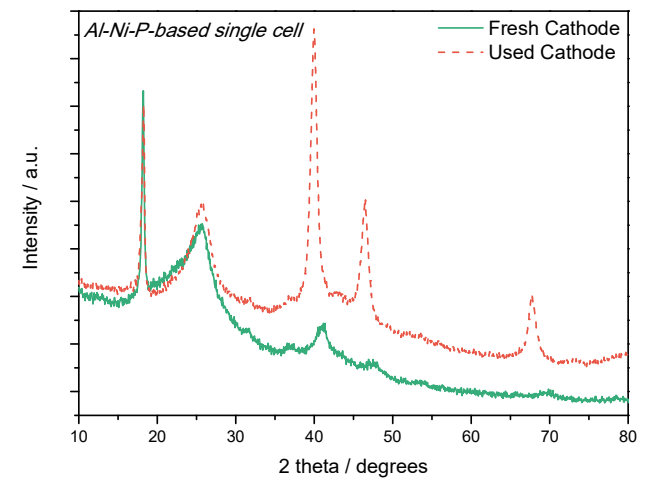

(d)

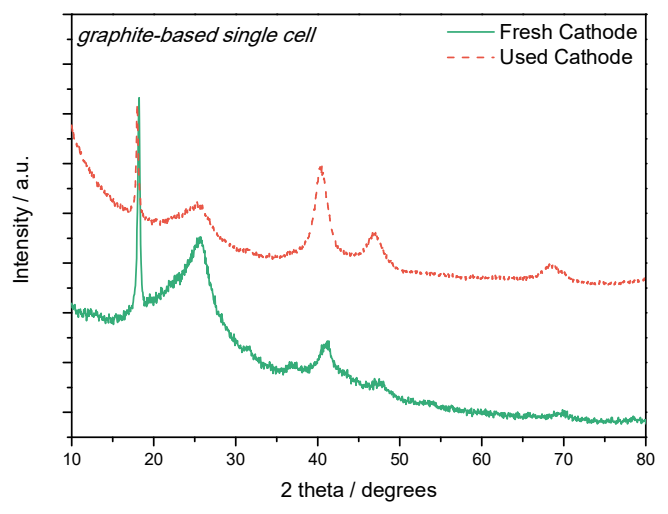

Figure 7. XRD diffraction patterns for both the anode and the cathode obtained from the fresh and the used MEAs for the (a) and (b) Al-Ni-P-based single cell and the (c) and (d) graphite-based single cell.

Crystallite sizes, shown in Table $\mathbf{1}$ and calculated from the Scherrer's equation, are $5.4 \mathrm{~nm}$ for the anode side and $8.9 \mathrm{~nm}$ for the cathode one (in comparison to $3.7 \mathrm{~nm}$ for the anode and $4.6 \mathrm{~nm}$ for the cathode of the fresh samples). XRD patterns shown in Fig. 7c and 7d for the used MEA in the graphite-based single cell, evidence the same trend that in the case of the Al-Ni-P-based cell. Pt crystal size increases after the degradation tests, particularly in the cathode side. In this case, crystallite sizes (Table 1) are $5.2 \mathrm{~nm}$ for the anode and $7.8 \mathrm{~nm}$ for the cathode. 
Table 1. Crystallite and particle size (nm) for Pt-catalysts from the different MEAs under study determined by XRD and TEM.

\begin{tabular}{lcccccc}
\hline \multirow{2}{*}{ Electrode } & \multicolumn{2}{c}{ Fresh MEA } & \multicolumn{2}{c}{ Al-Ni-P used MEA } & \multicolumn{2}{c}{ Graphite used MEA } \\
\cline { 2 - 7 } & $X R D$ & $T E M$ & $X R D$ & $T E M$ & $X R D$ & $T E M$ \\
\hline Cathode & 4.6 & 4.5 & 8.9 & $4-8$ & 7.8 & $4-8$ \\
Anode & 3.7 & 3.5 & 5.4 & $3-6$ & 5.2 & $2-7$ \\
\hline
\end{tabular}

293

294

TEM images (Fig. 8) for both the used anode and cathode electrodes of the two

cells reveal an increase in particle size of the Pt due to the degradation, as previously

corroborated by XRD. Table 1 also shows the interval of mean particle size obtained

297 measuring the size of the particles studied by TEM analyses. XRD and TEM corroborate

298 the slightly higher degradation suffered by the MEAs in the Al-Ni-P single cell in

comparison to the one using graphite plates. As previously discussed, the graphite-based cell shows a lower performance decay due to degradation. 

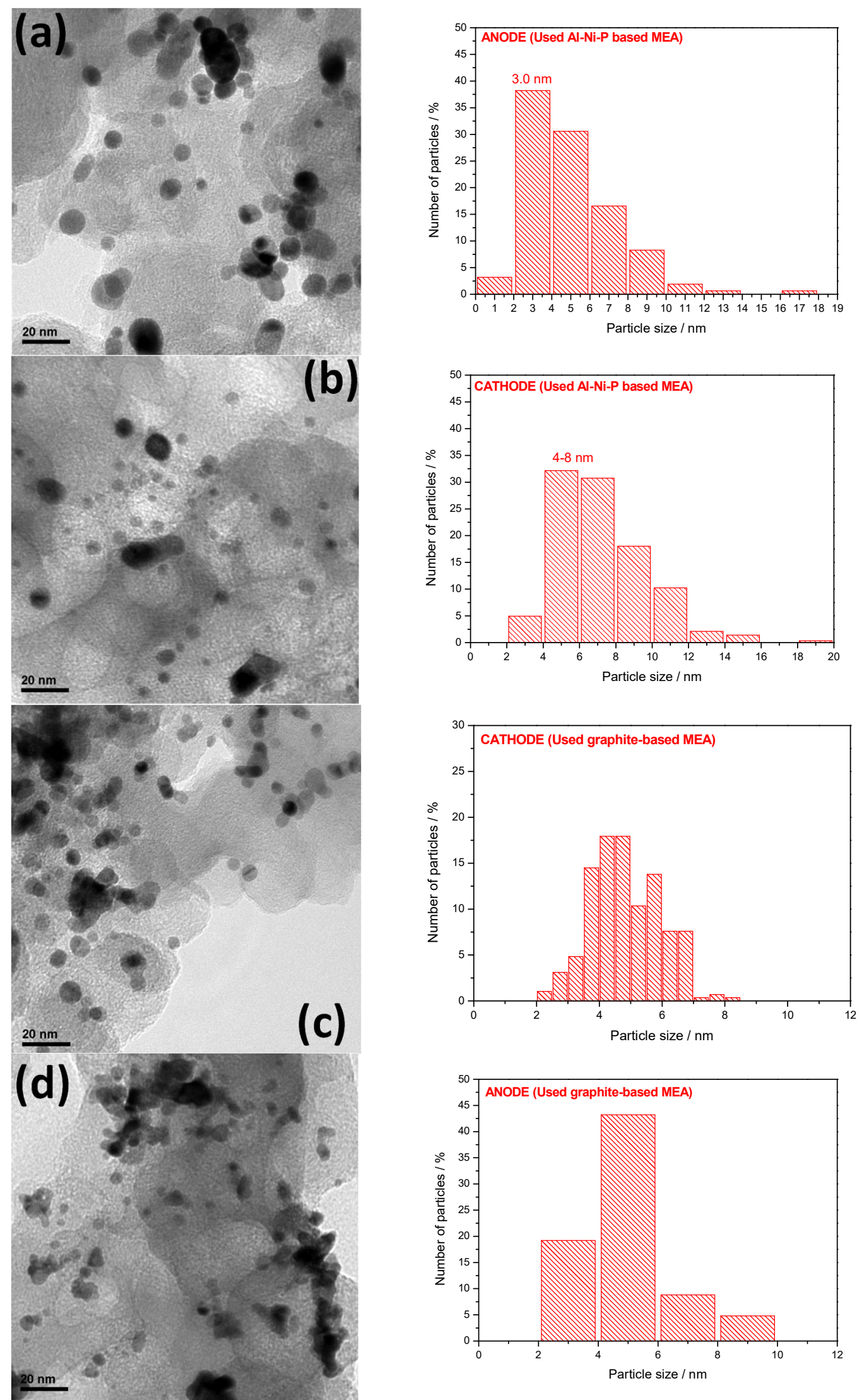

Figure 8. TEM images and particle size distribution for (a) used cathode and (b) used anode for the Al-Ni-P-based single cell and (c) cathode and (d) used anode for the graphite-based single cell. 

severe in the cathode side (due to a higher extent of agglomeration of Pt particles) and a preferential leaching of phosphoric acid towards the anode. This leaching affects more severely the Al-based cell, probably due to the deterioration of the surface coating that causes an increase in the contact resistance, as well as gas circulation problems caused by the obstruction of the flow-field channels.

Several recent articles claim that one of the main problems of HT-PEMFCs is the acid leaching from the PBI-membrane [6,18,24,56-59]. Bevilacqua et al. studied the insertion of phosphoric acid into gas diffusion layers of HT-PEMFCs. They determined that the structure of the microporous layer is determinant as a physical barrier to restrict the leaching of phosphoric acid through the GDL [24]. Myles et al. reviewed the challenges that HT-PEMFCs still face, the leaching of phosphoric acid being of paramount importance. These articles show the importance of designing improved membranes with minimized acid leaching in order to extent the durability of HT-PEMFCs $317 \quad[56]$.

The advantages of using metallic bipolar plates, which offered a significantly higher initial performance, are obvious: lower cost, lower weight, and easy manufacture, among others. Taking this into account, future studies will be addressed towards the optimization of the operational parameters, in order to mitigate the leaching of PA, allowing a high performance for a long time, as well as the use of improved PBI membranes. To this end, both experimental and modelling techniques will be employed. 


\section{Conclusions}

Low-cost Al-based plates were employed in a high-temperature PEM single cell.

329

New accelerated stress tests were designed and carried out to assess their feasibility in comparison with the commonly used graphite plates. The performance of the Al-based cell was initially better than that obtained for the graphite-based cell. However, its performance severely deteriorated due to the formation of a green deposit over the plates, due to the chemical reaction of the phosphoric acid leached from the MEA with the Ni-P coating. These deposits cause an increase in the contact resistance, local channel blockages and, eventually, a larger degradation.

In both cases, the two major contributions to degradation were the agglomeration of Pt particles and the leaching of phosphoric acid. The agglomeration of Pt particles was more severe in the cathode side for both cells, i.e, Al-based and graphite-based. For the cell formed by Al-based BPPs, Pt crystallite sizes increased from $3.7 \mathrm{~nm}$ for the fresh MEA anode to $5.4 \mathrm{~nm}$ for the used one and from $4.6 \mathrm{~nm}$ to $8.9 \mathrm{~nm}$ in the cathode electrode. The same trend, although slightly milder, was verified for the graphite-based cell. Leaching of PA is responsible of the decrease in the MEA thickness when Al-Ni-P plates were used. The thickness of the MEA from the graphite-based cell however, barely became affected by the degradation processes.

Al-based plates provide a better initial performance in comparison to the cell with graphite plates, being envisaged as adequate and low cost components for HT-PEMFC. However, to extend their durability several issues should be solved: (i) designing membranes with a better retention of the acid molecules, (ii) the optimization of the operational parameters of the cell, in order to minimize the acid leaching and (iii) other surface coating to metallic plates with a better corrosion resistance. The optimization of 
351 operational parameters and the use of new surface coating will be the focus of future

352 researches, in which both experimental tests and numerical studies will be considered.

\section{Acknowledgments}

355 Authors acknowledge the financial support of the Secretariat of State for Research of the 356 Spanish Ministry of Economy and Competitiveness under project DPI2015-69286-C3-1357 R (MINECO/FEDER, UE). Support of the Regional Government of Aragon to the 358 Experimental Fluid Dynamics Research Group (T03) of the LIFTEC is also 359 acknowledged. C. Alegre acknowledges the support of MINECO for her Juan de la Cierva 360 contract and L. Álvarez-Manuel acknowledges the funding provided by the European 361 Social Fund and CSIC under the Youth Employment Initiative. Authors also acknowledge 362 Dr. M Jesús Lázaro from the Instituto de Carboquímica for performing the physical363 chemical characterization. 


\section{References}

[1] Rosli RE, Sulong AB, Daud WRW, Zulkifley MA, Husaini T, Rosli MI, et al. A review of high-temperature proton exchange membrane fuel cell (HT-PEMFC) system. Int J Hydrogen Energy 2017;42:9293-314.

[2] Chandan A, Hattenberger M, El-kharouf A, Du S, Dhir A, Self V, et al. High temperature (HT) polymer electrolyte membrane fuel cells (PEMFC) - A review. J Power Sources 2013;231:264-78. doi:10.1016/J.JPOWSOUR.2012.11.126.

[3] Kannan A, Kabza A, Scholta J. Long term testing of start-stop cycles on high temperature PEM fuel cell stack. J Power Sources 2015;277:312-6. doi:10.1016/J.JPOWSOUR.2014.11.115.

[4] Zhu Y, Zhu WH, Tatarchuk BJ. Performance comparison between high temperature and traditional proton exchange membrane fuel cell stacks using electrochemical impedance spectroscopy. J Power Sources 2014;256:250-7. doi:10.1016/j.jpowsour.2014.01.049.

[5] Zhang L, Chae S-R, Hendren Z, Park J-S, Wiesner MR. Recent advances in proton exchange membranes for fuel cell applications. Chem Eng J 2012;204-206:87-97.

[6] Araya SS, Zhou F, Liso V, Sahlin SL, Vang JR, Thomas S, et al. A comprehensive review of PBI-based high temperature PEM fuel cells. Int J Hydrogen Energy 2016;41:21310-44. doi:10.1016/j.ijhydene.2016.09.024.

[7] Muthuraja P, Prakash S, Shanmugam VM, Radhakrsihnan S, Manisankar P. Novel perovskite structured calcium titanate-PBI composite membranes for hightemperature PEM fuel cells: Synthesis and characterizations. Int J Hydrogen Energy 2018;43:4763-72. doi:10.1016/J.IJHYDENE.2017.12.010.

[8] Cheng X, Shi Z, Glass N, Zhang L, Zhang J, Song D, et al. A review of PEM hydrogen fuel cell contamination: Impacts, mechanisms, and mitigation. J Power Sources 2007;165:739-56. doi:10.1016/J.JPOWSOUR.2006.12.012.

[9] Devrim Y, Albostan A, Devrim H. Experimental investigation of CO tolerance in high temperature PEM fuel cells. Int J Hydrogen Energy 2018. doi:10.1016/J.IJHYDENE.2018.05.085.

[10] Kojima K, Fukazawa K. Current Status and Future Outlook of Fuel Cell Vehicle Development in Toyota. ECS Trans 2015;69:213-9. doi:10.1149/06917.0213ecst.

[11] Niakolas DK, Daletou M, Neophytides SG, Vayenas CG. Fuel cells are a commercially viable alternative for the production of clean energy. Ambio 2016;45:32-7. doi:10.1007/s13280-015-0731-z.

[12] Aricò AS, Baglio V, Antonucci V. Nanomaterials for Fuel Cell Technologies. Nanotechnol. Energy Chall., Weinheim, Germany: Wiley-VCH Verlag GmbH \& Co. KGaA; n.d., p. 79-109. doi:10.1002/9783527629299.ch4.

[13] Taccani R, Chinese T, Boaro M. Effect of accelerated ageing tests on PBI HTPEM fuel cells performance degradation. Int J Hydrogen Energy 2017;42:1875-83. doi:10.1016/J.IJHYDENE.2016.09.164.

[14] Yu S, Xiao L, Benicewicz BC. Durability studies of PBI-based high temperature PEMFCs. Fuel Cells, 2008; 8:165-74. doi:10.1002/fuce.200800024. 
[15] Lufrano F, Gatto I, Staiti P, Antonucci V, Passalacqua E. Sulfonated polysulfone ionomer membranes for fuel cells. Solid State Ionics, vol. 145, p. 47-51. doi:10.1016/S0167-2738(01)00912-2.

[16] Wu J, Yuan XZ, Martin JJ, Wang H, Zhang J, Shen J, et al. A review of PEM fuel cell durability: Degradation mechanisms and mitigation strategies. J Power Sources 2008;184:104-19.

[17] Galbiati S, Baricci A, Casalegno A, Marchesi R. Degradation in phosphoric acid doped polymer fuel cells: A $6000 \mathrm{~h}$ parametric investigation. Int J Hydrogen Energy 2013;38:6469-80. doi:10.1016/J.IJHYDENE.2013.03.012.

[18] Hartnig C, Schmidt TJ. On a new degradation mode for high-temperature polymer electrolyte fuel cells: How bipolar plate degradation affects cell performance. Electrochim Acta 2011;56:4237-42. doi:10.1016/j.electacta.2011.01.088.

[19] Kim J-RR, Yi JS, Song T-WW. Investigation of degradation mechanisms of a high-temperature polymer-electrolyte-membrane fuel cell stack by electrochemical impedance spectroscopy. J Power Sources 2012;220:54-64. doi:10.1016/j.jpowsour.2012.07.129.

[20] Cleemann LN, Buazar F, Li Q, Jensen JO, Pan C, Steenberg T, et al. Catalyst degradation in high temperature proton exchange membrane fuel cells based on acid doped polybenzimidazole membranes. Fuel Cells 2013;13:822-31. doi:10.1002/fuce.201200186.

[21] Kerr R, García HR, Rastedt M, Wagner P, Alfaro SM, Romero MT, et al. Lifetime and degradation of high temperature PEM membrane electrode assemblies. Int $\mathrm{J}$ Hydrogen Energy 2015;40:16860-6. doi:10.1016/J.IJHYDENE.2015.07.152.

[22] Oh H-S, Lee J-H, Kim H. Electrochemical carbon corrosion in high temperature proton exchange membrane fuel cells. Int J Hydrogen Energy 2012;37:10844-9. doi:10.1016/j.ijhydene.2012.04.095.

[23] Valle F, Zuliani N, Marmiroli B, Amenitsch H, Taccani R. SAXS Analysis of Catalyst Degradation in High Temperature PEM Fuel Cells Subjected to Accelerated Ageing Tests. Fuel Cells 2014;14:938-44. doi:10.1002/fuce.201300221.

[24] Bevilacqua N, George MG, Galbiati S, Bazylak A, Zeis R. Phosphoric Acid Invasion in High Temperature PEM Fuel Cell Gas Diffusion Layers. Electrochim Acta 2017;257:89-98. doi:10.1016/J.ELECTACTA.2017.10.054.

[25] Fetohi AE, Abdel Hameed RM, El-Khatib KM. Ni-P and Ni-Mo-P modified aluminium alloy 6061 as bipolar plate material for proton exchange membrane fuel cells. J Power Sources 2013;240:589-97. doi:10.1016/J.JPOWSOUR.2013.04.085.

[26] Guerrero Moreno N, Cisneros Molina M, Gervasio D, Pérez Robles JF. Approaches to polymer electrolyte membrane fuel cells (PEMFCs) and their cost. Renew Sustain Energy Rev 2015;52:897-906. doi:10.1016/j.rser.2015.07.157.

[27] Wilberforce T, El-Hassan Z, Khatib FN, Al Makky A, Mooney J, Barouaji A, et al. Development of Bi-polar plate design of PEM fuel cell using CFD techniques. Int J Hydrogen Energy 2017;42:25663-85. 
[28] Tsai S-Y, Bai C-Y, Lin C-H, Shi G-N, Hou K-H, Liu Y-M, et al. The characteristics and performance of electroless nickel and immersion Au plated aluminum alloy bipolar plates in polymer electrolyte membrane fuel cells. J Power Sources 2012;214:51-8. doi:10.1016/J.JPOWSOUR.2012.04.030.

[29] Scholta J, Messerschmidt M, Jörissen L, Hartnig C. Externally cooled high temperature polymer electrolyte membrane fuel cell stack. J Power Sources 2009;190:83-5. doi:10.1016/J.JPOWSOUR.2008.10.124.

[30] Rajaei V, Rashtchi H, Raeissi K, Shamanian M. The study of Ni-based nanocrystalline and amorphous alloy coatings on AISI 304 stainless steel for PEM fuel cell bipolar plate application. Int J Hydrogen Energy 2017;42:14264-78. doi:10.1016/J.IJHYDENE.2017.04.098.

[31] Hermann A, Chaudhuri T, Spagnol P. Bipolar plates for PEM fuel cells: A review. Int J Hydrogen Energy 2005;30:1297-302. doi:10.1016/J.IJHYDENE.2005.04.016.

[32] Lin CH, Tsai SY. An investigation of coated aluminium bipolar plates for PEMFC. Appl Energy 2012;100:87-92. doi:10.1016/j.apenergy.2012.06.045.

[33] Renau J, Barroso J, Lozano A, Nueno A, Sánchez F, Martín J, et al. Design and manufacture of a high-temperature PEMFC and its cooling system to power a lightweight UAV for a high altitude mission. Int $\mathrm{J}$ Hydrogen Energy 2016;41:19702-12. doi:10.1016/j.ijhydene.2015.12.209.

[34] Alnegren P, Grolig JG, Ekberg J, Göransson G, Svensson J-EE. Metallic Bipolar Plates for High Temperature Polymer Electrolyte Membrane Fuel Cells. Fuel Cells 2016;16:39-45. doi:10.1002/fuce.201500068.

[35] Weissbecker V, Wippermann K, Lehnert W. Electrochemical Corrosion Study of Metallic Materials in Phosphoric Acid as Bipolar Plates for HT-PEFCs. J Electrochem Soc 2014;161:F1437-47. doi:10.1149/2.0691414jes.

[36] Barreras F, Lozano A, Roda V, Barroso J, Martín J. Optimal design and operational tests of a high-temperature PEM fuel cell for a combined heat and power unit. Int. J. Hydrogen Energy 2014; 39:5388-98. doi:10.1016/j.ijhydene.2013.11.070.

[37] Richards J, Schmidt K, Cremers C, Tübke J, Lückmann A. Investigation of the Corrosion Stability of Stainless Steels under Simulated Low and High Temperature Proton Exchange Membrane Fuel Cell Operating Conditions. ECS Trans., vol. 25, ECS; 2009, p. 747-55. doi:10.1149/1.3210626.

[38] Tseng C-J, Heush Y-J, Chiang C-J, Lee Y-H, Lee K-R. Application of metal foams to high temperature PEM fuel cells. Int J Hydrogen Energy 2016;41:16196-204. doi:10.1016/J.IJHYDENE.2016.06.149.

[39] Wind J, Späh R, Kaiser W, Böhm G. Metallic bipolar plates for PEM fuel cells. J Power Sources 2002;105:256-60. doi:10.1016/S0378-7753(01)00950-8.

[40] El-Enin SAA, Abdel-Salam OE, El-Abd H, Amin AM. New electroplated aluminum bipolar plate for PEM fuel cell. J Power Sources 2008;177:131-6. doi:10.1016/J.JPOWSOUR.2007.11.042. 
[41] Lin J-Y, Lin C-Y, Liu S-K, Wan C-C, Wang Y-Y. Characterization of electroless Ni-based alloys for use in bipolar plates of direct methanol fuel cells. Surf Coatings Technol 2010;205:2251-5. doi:10.1016/J.SURFCOAT.2010.09.003.

[42] Tawfik H, Hung Y, Mahajan D. Metal bipolar plates for PEM fuel cell-A review. J Power Sources 2007;163:755-67. doi:10.1016/J.JPOWSOUR.2006.09.088.

[43] Schmittinger W, Vahidi A. A review of the main parameters influencing long-term performance and durability of PEM fuel cells. J Power Sources 2008;180:1-14. doi:10.1016/J.JPOWSOUR.2008.01.070.

[44] Hengge K, Heinzl C, Perchthaler M, Varley D, Lochner T, Scheu C. Unraveling micro- and nanoscale degradation processes during operation of high-temperature polymer-electrolyte-membrane fuel cells. J Power Sources 2017;364:437-48. doi:10.1016/J.JPOWSOUR.2017.08.042.

[45] Wannek C, Konradi I, Mergel J, Lehnert W. Redistribution of phosphoric acid in membrane electrode assemblies for high-temperature polymer electrolyte fuel cells. Int J Hydrogen Energy 2009;34:9479-85. doi:10.1016/j.ijhydene.2009.09.076.

[46] Lobato J, Cañizares P, Rodrigo MA, Linares JJ, Pinar FJ. Study of the influence of the amount of PBI-H3PO4 in the catalytic layer of a high temperature PEMFC. Int J Hydrogen Energy 2010;35:1347-55. doi:10.1016/j.ijhydene.2009.11.091.

[47] Zhang JJ, Tang Y, Song C, Zhang JJ. Polybenzimidazole-membrane-based PEM fuel cell in the temperature range of $120-200^{\circ} \mathrm{C}$. J Power Sources 2007;172:16371. doi:10.1016/j.jpowsour.2007.07.047.

[48] Oshiba Y, Tomatsu J, Yamaguchi T. Thin pore-filling membrane with highly packed-acid structure for high temperature and low humidity operating polymer electrolyte fuel cells. J Power Sources 2018;394:67-73. doi:10.1016/J.JPOWSOUR.2018.05.013.

[49] Barreras F, Lozano A, Valiño L, Marín C, Pascau A. Flow distribution in a bipolar plate of a proton exchange membrane fuel cell: experiments and numerical simulation studies. J Power Sources 2005;144:54-66. doi:10.1016/J.JPOWSOUR.2004.11.066.

[50] Lozano A, Barreras F, Valiño L, Marín C. Imaging of gas flow through a porous medium from a fuel cell bipolar plate by laser-induced fluorescence. Exp Fluids 2007;42:301-10. doi:10.1007/s00348-006-0241-7.

[51] Lozano A, Valiño L, Barreras F, Mustata R. Fluid dynamics performance of different bipolar plates: Part II. Flow through the diffusion layer. J Power Sources 2008;179:711-22. doi:10.1016/J.JPOWSOUR.2007.12.095.

[52] Barreras F, Lozano A, Valiño L, Mustata R, Marín C. Fluid dynamics performance of different bipolar plates: Part I. Velocity and pressure fields. J Power Sources 2008;175:841-50. doi:10.1016/J.JPOWSOUR.2007.09.107.

[53] Schonvogel D, Rastedt M, Wagner P, Wark M, Dyck A. Impact of Accelerated Stress Tests on High Temperature PEMFC Degradation. Fuel Cells 2016;16:4809. doi:10.1002/fuce.201500160.

[54] Reimer U, Ehlert J, Janßen H, Lehnert W. Water distribution in high temperature 
polymer electrolyte fuel cells. Int J Hydrogen Energy 2016;41:1837-45. doi:10.1016/j.ijhydene.2015.11.106.

[55] Eberhardt SH, Toulec M, Marone F, Stampanoni M, Buchi FN, Schmidt TJ. Dynamic Operation of HT-PEFC: In-Operando Imaging of Phosphoric Acid Profiles and (Re)distribution. J Electrochem Soc 2015;162:F310-6. doi:10.1149/2.0751503jes.

[56] Myles T, Bonville L, Maric R. Catalyst, Membrane, Free Electrolyte Challenges, and Pathways to Resolutions in High Temperature Polymer Electrolyte Membrane Fuel Cells. Catalysts 2017;7:16. doi:10.3390/catal7010016.

[57] De Beer C, Barendse PS, Pillay P, Bullecks B, Rengaswamy R. Classification of high-temperature PEM fuel cell degradation mechanisms using equivalent circuits. IEEE Trans Ind Electron 2015;62:5265-74. doi:10.1109/TIE.2015.2393292.

[58] Kim J-R, Yi JS, Song T-W. Investigation of degradation mechanisms of a hightemperature polymer-electrolyte-membrane fuel cell stack by electrochemical impedance spectroscopy. J Power Sources 2012;220:54-64. doi:10.1016/j.jpowsour.2012.07.129.

[59] Matar S, Higier A, Liu H. The effects of excess phosphoric acid in a Polybenzimidazole-based high temperature proton exchange membrane fuel cell. J Power Sources 2010;195:181-4. doi:10.1016/J.JPOWSOUR.2009.06.084. 